\title{
RISK MANAGEMENT PRACTICES AND PROFITABILITY OF MICROFINANCE BANKS IN RWANDA ACASE OF URWEGO BANK
}

\author{
Lydia GAHONGAYIRE ${ }^{1 *}$, Mercyline KAMANDE ${ }^{2}$ \\ ${ }^{*}$ School of Business and Economics, Business Administration (MBA), Finance, Mount Kenya University, Kigali, \\ Rwanda,lgahongayire85@gmail.com \\ ${ }^{2}$ Mount Kenya University, mkamande@mku.ac.ke2
}

*Corresponding Author: -

Email: lgahongayire85@gmail.com

\begin{abstract}
: -
Financial institutions are major players in the economic development of a country by offering channels through which funds flow from one source to another. However, they are faced with numerous risks in their daily operations. The main goal behind the current research was to assess the effect of risk management practices on the profitability of microfinance banks in Rwanda, a case of Urwego Bank. Both descriptive and correlational research designs were used. Data was collected from the targeted population of 113 employees in Urwego Bank who were considered for the sampling using the census method. The data was collected using structured questionnaire and interview guide for key informants. The research instrument reliability test was done using Cronbach's alpha test while the validity was achieved through revision of the questionnaire after a pre-test is conducted. The data that collected was analyzed using SPSS through which data was presented using frequency tables, descriptive statistics, and regression analysis. The findings on risk assessment revealed that $77.8 \%$ of the respondents agreed that they can conduct risk identification. A total of $63.4 \%$ of the respondents agreed on the importance of risk classification. The regression analysis revealed that there is combined effect of risk measurement, risk identification and risk classification on the profitability of the bank giving an $R^{2}$ of 0.418 . On whether having control measures within a bank can greatly assist in effective risk management, $82.5 \%$ of the respondents agreed. $73 \%$ of the respondents agreed that risk mitigation strategies are effective ways of reducing the possibility of occurrence of risk and their impact in an organization. $74.1 \%$ of respondents showed that risk financing is important for the Bank in its management of risk. Further, regression analysis showed the model was fit at $5 \%(\mathrm{~F}=27.388, \mathrm{p}<0.05)$ and an $R^{2}=0.582$ indicating that the changes in profitability of the Bank are influenced by risk control measures. The regression model regarding the risk monitoring was found to be significant $(\mathrm{F}=6.652, \mathrm{p}<0.05)$ and an $\mathrm{R}^{2}=0.253$ showing that the profitability in Urwego Bank is influenced by risk monitoring processes. The overall regression model was significant $(\mathrm{F}=22.695, \mathrm{p}<0.05)$ and an $R^{2}=0.536$ and showed that risk management practices should be practiced in totality to ensure that effective results are obtained. Therefore, the researcher recommended that policy makers and supervisors, including the central bank, should be more vigilant in promulgating the culture of risk management in the banks especially for microfinance banks which are few in the industry.
\end{abstract}

Keywords: - Risk Management Practices, Profitability, Microfinance Banks, Urwego Bank, Rwanda

\section{(우 (웅}




\section{INTRODUCTION}

For banks to be able to continue sustaining their operations, they should be able to make profit from their operations. However, exposure to risks can harm the operation of the bank and can lead to losses. Therefore, there is need for the banks to be able to identify and adequately deal with the risks that they face. As financial institutions, banks are by their very nature of business exposed to various risks that are particular to their operation, for instance, credit risks, interest risks, operational risks, market risks, among others. Effective risk management which a bank adopts can help in minimizing the possible occurrence and possible loss associated with the risks. However, the banks in Rwanda have continued to experience risk related losses arising from fraud risk, default risk, operational risks, and foreign exchange risks. These clearly show that the need for effective risk management practices to address these and other risks to enhance the profitability of the banks. Research by Lee (2014) on the MFBs and NB MFIs in Rwanda highlighted risk management as a challenge that face these institutions especially due to their relatively small size, lack of experience, lack of professional skills and less financial capability.

In addition, the MFBs compare relatively weak with the large counterpart financial institutions like commercial banks in terms of their capacity to assess credit worthiness of clients. Similarly, there is limited empirical research that focuses on risk management for these institutions. Most of the research in this topic of risk management focuses on commercial banks and this has been identified as a research gap that needs to be addressed. For instance, Sabeza, Shukla and Bajpai (2015) research focuses on the risk management within the commercial banks in Rwanda. In another research, Byamungu, Nkechi and Ogoi (2019) carried out their research on how risk management practices affect investing decision in commercial banks in Rwanda. Moreover, the industry of microfinance bank is relatively young in Rwanda and with only three MFBs.

Therefore, the present research was carried out to fill this research gap and investigated the effect of risk management practices on the profitability of microfinance banks in Rwanda, a case of Urwego Bank.

\subsection{Objectives of the study \\ 1.1.1 General objective}

The general objective of this study was to examine the effect of risk management practices on profitability microfinance banks in Rwanda, a case of Urwego Bank.

\subsubsection{Specific objectives}

i) To determine the effect of risk assessment on the profitability of Urwego Bank, Rwanda.

ii) To investigate the effect of risk control measures on profitability of Urwego Bank, Rwanda.

iii) To investigate the effect of risk monitoring on the profitability of Urwego Bank, Rwanda.

\section{Review of Literature}

\subsection{Risk Assessment and Profitability of Banks}

Solomon and Muntean in their research carried out in concentrated on the assessment of financial risk and how this influences profitability of commercial banks. They however concentrated on financial risk only. Hallunovi and Berdo (2018) in their research focused on finding out whether a relationship exists between risk management and commercial banks profitability in Albania. The main concern was on credit risk and in what way this could influence the profitability of commercial banks. The research identified four variables which were used to achieve the study objectives, namely, ROA and ROE' as dependent' variables and nonperforming loans (NPLs) and Capital adequacy ratio (CAR) as the predictor variables. The research used data obtained from financial reports as secondary data, for seven years from 2000 to 2015, of which it was entered into SPSS and analysis done' using multiple' regression analysis model. The results showed that the two models were significant $(\mathrm{p}<0.05)$ with the adjusted R squared for ROA being 0.579 and for ROE as 0.642 . The conclusion then showed that risk management is highly related to the commercial bank's profitability.

Zou and $\mathrm{Li}$ (2014) were also concerned about the effect of credit risk management on commercial banks profitability in Europe in their research. Taking a sample of 47 largest commercial banks in Europe and for a period of 6 years (2007-2012), the authors formulated and tested four hypotheses to achieve their research objectives. NPL and CAR were used as proxies for dependent variable (risk management) while ROA and ROE were used for profitability measurement. The authors in their literature explored various empirical evidence related to their study and highlighted the credit management as one of the areas that has received much attention in literature. Moreover, their arguments and the choice of the variables to include in the study were informed by their extensive empirical review. The authors used explanatory research design and used multivariate regression analysis to conduct the data analysis. The results showed an $\mathrm{R}^{2}$ of 0.106 for ROE and 0.089 for ROA. This revealed there exists positive but week correlation' between the independent and dependent variables.

\subsection{Risk Control Measures and Profitability of Banks}

Another related empirical research was conducted by Irawati and Maksum (2018) conducted in Indonesia. This research investigated commercial bank profitability in Indonesia and how this profitability is influenced by risk management and bank size. To achieve their objective, the researchers took a sample of thirty listed commercial banks in the Indonesia Stock Exchange (IDX) and five years from 2011 to 2015. The use of regression analysis in a panel data framework showed that a positive and significant correlation exists between CAR and ROA ( $r=0.266$, 
$\mathrm{p}<0.05)$, a negative and significant correlation exists between NPL and ROA $(\mathrm{r}=-0.421, \mathrm{p}<0.05)$ and a positive and significant relationship exist between firm size and profitability $(r=0.424, \mathrm{p}<0.05)$.

Olalekan, Olumide and Irom (2018) on their part concentrated on financial risk management and how this affect profitability of commercial banks in Nigeria. A sample of fourteen listed commercial banks was selected and the data obtained from their respective financial reports covering a period of seven years (2011-2016). In the research, profitability was measured using ROA while liquidity risk, credit risk and capital adequacy risk were used for the independent variable, financial risk management. Risk controls, the results obtained from multiple regression analysis revealed that the model were significant with liquidity risk $(r=0.28, \mathrm{p}<0.05)$ and capital adequacy risk $(\mathrm{r}=0.271, \mathrm{p}<0.05)$ having positive and significant effect on profitability. Credit risk was found to have a negative and significant $(\mathrm{r}=-0.514, \mathrm{p}<0.05)$ effect on profitability. The overall $\mathrm{R}^{2}$ was found to be 0.316 . They also highlight the need for the banks to put control measures to deal with the risks they encounter.

\subsection{Risk Monitoring and Profitability of Banks}

Empirical research on the need for effective risk monitoring has also been highlighted in previous research. For instance, while taking a sample of 83 commercial banks in US. Sun and Chang (2018) carried out empirical research investigating the interconnection on credit risk and profitability. It covered the period from 2010 to 2017 and estimate the OLS regressions with CAR and NPL measuring credit risk and ROA and ROE measuring profitability. According to their findings NPL is negatively correlated to both ROA and ROE, CAR is positively related to ROA but negatively to ROE while size is positively related to both ROA and ROE. Risk monitoring was also indicated as important for the commercial banks in managing credit risk.

Kamau (2010) conducted empirical research investigating the adoption of risk management practices by the commercial banks in Kenya. Taking a census of 44 commercial banks, the researcher collected data using questionnaire and financial statements. The research revealed that commercial banks in Kenya use both qualitative and quantitative risk management practices. Some of these risk practices include risk monitoring which enable the bank to be proactively involved in the risk management process. Another research also carried out in Kenya by Mohamed and Onyiego (2018) investigated the effect of risk management practices on the' performance of commercial banks` in Mombasa County. The study revealed that operational, credit and liquidity risks are some of the main risks that affect the profitability of commercial banks` in Kenya.

In Rwanda, Rwayitare, Shukla and Ruhara (2016) conducted a research on the credit risk' management and commercial bank profitability in Rwanda. The research used quantitative analysis and tested for normality and cointegration to determine the Granger causality among the study variables. The findings showed that there exists both short and long run significant correlation between credit risk management and profitability. Ugirase (2013) in her research investigated credit risk management and its effect on ' the financial performance of' commercial banks in Rwanda. The research design adopted was descriptive research design and collected data using questionnaire. The research involved all the 11 commercial banks in Rwanda and data was analyzed using SPSS 17. The analysis showed the model to be significant $(\mathrm{p}<0.05)$ with an $\mathrm{R}^{2}$ of 0.986 . The results showed that risk monitoring, risk scoring, and credit analysis were all significantly related to financial performance of the commercial banks. Risk identification was however found not to be significant to performance.

\subsection{Research Gap}

The majority of the research investigated focused on credit risk management while others concentrated on commercial banks. Two of the research focused on risk management practices but failed to highlight and discuss the practices (Kamau, 2010 and Mohammed and Onyiego, 2018). The studies did not pay attention to the risk management practices or process adopted by the commercial banks. The current research intends to fill these research gaps that were identified. First, this study centers on risk management practices which include risk assessment, risk' control measures and risk monitoring. To the best of the research knowledge no research identified had focused on these variables. Secondly, there is much focus on commercial banks while no research was identified related to microfinance banks.

\section{Materials and Methods}

This study used both descriptive and correlational research designs. The main departments involved are finance, compliance, internal audit, credit and recovery, information technology (IT), human resource (HR), Operations and marketing whose total number of employees are 113. In this research, the entire target population was small and therefore was used for this research. Consequently, 113 staff members were considered as the sample size to provide the primary data required in this research. Since, the target population was small, the researcher used census method which allowed the use of all the staff in the targeted departments. Thus, this research utilized both secondary and' primary data. The secondary data was collected from Urwego Bank annual financial statement as secondary sources. To collect the primary data, structured questionnaires were used.

The questionnaires were administered to the selected respondents in their respective offices by the researcher. In this case the technique that used was drop-and-pick where the questionnaires were left with the respondents and later collected for analysis purpose. As soon as the data was collected from the field using questionnaire and from secondary sources, it was coded, entered in SPSS version 21, cleaned for missing variables, and stored ready for analysis. Since the statements in the questionnaire use Likert scale from 1 to 5 , a response of five was considered as a score of five, a response of four as score of four, and so on. These scores were combined through data 
transformation using SPSS to derive the variables for correlation and regression analysis. Once this was achieved, data analysis began with first descriptive statistics, summary of frequency tables and charts.Further, regression analyses were carried out with the main regression model which is $\mathrm{Y}=\mathrm{p}_{0}+\mathrm{p}_{1} \mathrm{X}_{1}+\mathrm{p}_{2} \mathrm{X}_{2}+\mathrm{p}_{3} \mathrm{X}_{3}+\mathrm{c}$ Where $\mathrm{Y}=$ is the profitability, $\mathrm{X} 1, \mathrm{X} 2, \mathrm{X} 3=$ Risk Assessment, Risk Control measures and Risk monitoring respectively, $\mathrm{p}_{0}=$ Constant and whereas, $\mathrm{p}_{1}, \mathrm{p}_{2}$, and $\mathrm{p}_{3}=$ Coefficients of regression.

\section{Research Findings}

4.1 Findings on the effect of risk assessment on the profitability of Urwego Bank, Rwanda

Table 4. 1: Respondents' awareness on risk management

\begin{tabular}{|c|c|c|c|c|c|c|}
\hline & \multicolumn{2}{|c|}{ Yes } & \multicolumn{2}{|l|}{ No } & \multicolumn{2}{|c|}{ Not Sure } \\
\hline & $\mathrm{N}$ & $\%$ & & $\%$ & $\mathrm{n}$ & $\%$ \\
\hline Are you aware of risk assessment procedures in Urwego Bank? & 45 & $71.4 \%$ & 10 & $15.9 \%$ & 8 & $12.7 \%$ \\
\hline Have you ever being involved in risk assessment in the Bank? & 21 & $33.3 \%$ & 26 & $41.3 \%$ & 16 & $25.4 \%$ \\
\hline Have you ever identified and reported any risk while working in the Bank? & 16 & $25.4 \%$ & 44 & $69.8 \%$ & 3 & $4.8 \%$ \\
\hline
\end{tabular}

Source: Primary data (2021)

The results in Table 4.1 regarding whether the respondents are aware of the risk assessment procedures in Urwego Bank, $71.4 \%$ said yes while $15.9 \%$ said no. The rest, that is, $12.7 \%$ of the respondents indicated that they are not sure. Out of all the respondents involved in this research, 33.3\% indicated that they have ever been involved in risk assessment within the Bank. However, only $25.4 \%$ have ever identified and reported risk while working in the Bank. The overall results from these findings show that risk assessment is practiced in Bank and through this process; different risks have been identified and reported.

Table 4.2: Respondents' views on riskidentification

\begin{tabular}{|c|c|c|c|c|c|c|c|c|c|c|c|}
\hline & SD & D & & $\mathrm{N}$ & & $\mathrm{A}$ & & SA & & & \\
\hline & n \% & $\mathrm{n}$ & $\%$ & $\mathrm{n}$ & $\%$ & $\mathrm{n}$ & $\%$ & $\mathrm{~N}$ & $\%$ & Mean & Std. \\
\hline $\begin{array}{l}\text { I am able to identify any financial risk in my } \\
\text { department }\end{array}$ & $11.6 \%$ & 3 & $4.8 \%$ & 10 & $15.9 \%$ & 32 & $50.8 \%$ & 17 & $27.0 \%$ & 3.97 & .88 \\
\hline $\begin{array}{l}\text { I thoroughly counter check any clients } \\
\text { request and transactions to ensure no errors } 1 \\
\text { or omissions }\end{array}$ & $11.6 \%$ & 2 & $3.2 \%$ & 12 & $19.0 \%$ & 28 & $44.4 \%$ & 20 & $31.7 \%$ & 4.02 & .89 \\
\hline $\begin{array}{l}\text { We work closely together as a team in } \\
\text { verification of transaction and procedures to } 0 \\
\text { be followed in completing the transaction }\end{array}$ & $0 \quad 0.0 \%$ & 0 & $0.0 \%$ & 5 & $7.9 \%$ & 51 & $81.0 \%$ & 7 & $11.1 \%$ & 4.03 & .44 \\
\hline $\begin{array}{l}\text { There are effective channels for reporting } \\
\text { identified risks in the Bank }\end{array}$ & $0 \quad 0.0 \%$ & 3 & $4.8 \%$ & 3 & $4.8 \%$ & 47 & $74.6 \%$ & 10 & $15.9 \%$ & 4.02 & .63 \\
\hline Overall & & & & & & & & & & 4.01 & 0.71 \\
\hline
\end{tabular}

Source: Primary data (2021)

Table 4.2 shows different responses obtained in this regard. On whether the respondent can identify any financial risk in the workplace, $50.8 \%$ were in agreement and $27 \%$ strongly agreed with the statement. The results therefore point that a total of $77.8 \%$ of the respondents can conduct risk identification. This is further supported by $44.4 \%$ and $31.7 \%$ of the respondents who agreed and strongly agreed that they do a thorough counter check of transaction to eliminate possibilities of error.

On whether the respondents work closely together as a team in verification of transaction and procedures for transaction, $82 \%$ of the respondents were in agreement and another $11.1 \%$ in strong agreement. This meant that $91.1 \%$ of the respondents agreed about the verification procedures within the Bank and involves all the staff. Only $7.9 \%$ of the respondents indicated they were neutral. The mean score obtained was 4.03 indicating agreement while a standard deviation of 0.44 is less than 0.5 , hence showing homogeneity of the responses. Respondents' views on whether there are effective channels for reporting identified risks in the Bank resulted to $74.6 \%$ of the respondents who agreed while $15.9 \%$ strongly agreed. This gave a total of $90.5 \%$ who agreed. The mean score of $4.02(\mathrm{SD}=0.63)$ also supports this result.

In addition, looking at the mean scores obtained on assessment, it is evidence that the lowest mean is $3.97(\mathrm{SD}=0.88)$ and the highest is $4.03(\mathrm{SD}=0.44)$. This was a proof that all in all the respondents agreed that risk assessment as measured by these statements is important in risk management practice. As a matter of fact, the overall mean of $4.01(\mathrm{SD}=0.71)$ clearly shows that even if there were divergence views, majority of the respondents were in agreement that risk assessment is an important factor that contributes to risk management in the Bank. On their part, Rwayitare, et al., (2016) revealed that there exists both a short run and a long run effect of risk management on the performance of organizations. 
Table 4.3 Respondent's view on risk classification

\begin{tabular}{llllll}
$\mathrm{SD}$ & $\mathrm{D}$ & $\mathrm{N}$ & $\mathrm{A}$ & $\mathrm{SA}$ & \\
\hline $\mathrm{N} \%$ & $\mathrm{n} \%$ & $\mathrm{n} \%$ & $\mathrm{~N} \%$ & $\mathrm{n} \%$ & MeanStd.
\end{tabular}

In order to effectively identify and manage risk, risks $00.0 \% 1320.6 \% 1015.9 \% 2844.4 \% 1219.0 \% 3.62 \quad 1.02$
should be well classified into various groups

The Bank always perform a market and company

assessment to provide a guide on the various risk's0 $0.0 \% 1 \quad 1.6 \% 7 \quad 11.1 \% 3657.1 \% 1930.2 \% 4.16 .68$

exposures.

Majority of the employees are aware of the various risks $11.6 \% 1 \quad 1.6 \% \quad 1625.4 \% 1117.5 \% 3454.0 \% 4.21 .99$

the Bank faces

Risk reporting is done as per each of the class within the ${ }_{1} 1.6 \% 3 \quad 4.8 \% 4 \quad 6.3 \% 3555.6 \% 2031.7 \% 4.11 .84$

Bank Different risks affecting the Bank are handled differently
and by different people/departments

Overall

$S D=$ strongly disagree, $D=$ disagree, $N=$ neutral, $A=$ agree, $S A=$ strongly agree, std.$=$ standard deviation

Source: Primary data (2021)

The results in Table 4.3 indicates that a total of $63.4 \%$ of the respondents agreed as made up of $44.4 \%$ and $19 \%$ who agreed and strongly agreed respectively. The mean score obtained was 3.62( $\mathrm{SD}=1.02)$ showing divergence in views. Similar results were obtained on whether the Bank always perform a market and company assessment to provide a guide on the various risks exposures a majority in agreement (87.3\%) as composed of $57.1 \%$ and $30.2 \%$ who agreed and strongly agreed with the statement. A mean of 4.16 and standard deviation of 0.68 were obtained. For the other statement about the employees' awareness of the various risks the Bank faces, 54\% strongly agreed and $17.5 \%$ agreed. Only $1.6 \%$ disagreed and another $1.6 \%$ strongly disagreed with the statement. This gave a mean of 4.21 and standard deviation of 0.99 . On whether risk reporting is done as per each of the class within the Bank 55.6\% agreed and $31.7 \%$ strongly agreed. The mean of 4.11(SD=0.84) clearly indicated majority agreed with the statement. Lastly, on the statement that different risks affecting the Bank are handled differently and by different people/departments, a total of $85.7 \%$ of the respondents agreed giving a mean score of $4.29(\mathrm{SD}=0.75)$. The overall mean of 4.08 showed that in general, despite the standard deviation $(\mathrm{SD}=0.86)$ showing divergence of views, the respondents agreed that risk classification is an important aspect in risk assessment. These results are indicated in similar research by Raghavan (2017) whose research highlighted the importance of risk assessment in the banking industry. However, Ugirase (2011) had previously found that there is no significant effect of risk identification on performance of commercial banks.

Table 4.4 Respondent's view on risk measurement

\begin{tabular}{|c|c|c|c|c|c|c|}
\hline & \multirow{2}{*}{$\frac{\mathrm{SD}}{\mathrm{n} \%}$} & \multirow{2}{*}{$\begin{array}{l}\mathrm{D} \\
\mathrm{n} \%\end{array}$} & \multirow{2}{*}{$\frac{\mathrm{N}}{\mathrm{N} \%}$} & \multirow{2}{*}{$\frac{\mathrm{A}}{\mathrm{N} \%}$} & \multicolumn{2}{|l|}{ SA } \\
\hline & & & & & n $\%$ & MeanStd. \\
\hline The Bank practices risk measurement in all its departments & $11.6^{0}$ & 23.2 & $046.3 \%$ & 711. & 04977. & $04.60 \quad .87$ \\
\hline $\begin{array}{l}\text { There is adequate screening techniques for all transactions at } \\
\text { borrowers as a measure to manage risks }\end{array}$ & $\mathrm{d}_{00.0^{\circ}}$ & 600.0 & $034.8 \%$ & 1117. & & $64.73 \quad 5$ \\
\hline $\begin{array}{l}\text { The practice of quantifying the impact of risk is carried out } \\
\text { a separate department }\end{array}$ & $\mathrm{y}_{00.0^{\circ}}$ & 34.8 & 1117. & 2234 & & 64.16 .88 \\
\hline $\begin{array}{l}\text { There is quality procedures followed as a measure for lo } \\
\text { disbursement in the Bank }\end{array}$ & $\mathrm{n}_{00.0^{\circ}}$ & & & & & \\
\hline $\begin{array}{l}\text { All the employees are aware of the effect of each risk exposu } \\
\text { to the Bank and therefore are careful to report any suspicio } \\
\text { dealings }\end{array}$ & e $00.0^{\circ}$ & 000.0 & $034.8 \%$ & 1625 & & $04.65 \quad .57$ \\
\hline Overall & & & & & & $4.40 \quad .72$ \\
\hline
\end{tabular}

SD=strongly disagree, $D=$ disagree, $N=$ neutral, $A=$ agree, $S A=$ strongly agree, std. $=$ standard deviation

Source: Primary data (2021)

Table 4.4 shows the results obtained regarding risk measurement as a key indicator of risk assessment. On whether the bank practices risk measurement in all its departments, $77.8 \%$ strongly agreed while $11.1 \%$ agreed, giving a total of $88.8 \%$ of respondents in agreement. The mean score of $4.6(\mathrm{SD}=0.87)$ was obtained. On whether there are adequate screening techniques for all transactions and borrowers, $77.8 \%$ of the respondents were in strong agreement and $17.5 \%$ in agreement. The mean obtained was 4.73 and standard deviation of 0.54 which showed homogeneity in the responses. On whether the practice of quantifying the impact of risk is carried out by a separate department, $42.9 \%$ of the respondents strongly agreed and $34.9 \%$ agreed with the statement bringing it to a total of $77.8 \%$ of respondents in agreement. $17.5 \%$ of the respondents indicated they were neutral while only $4.8 \%$ disagreed.

The average of $4.16(\mathrm{SD}=0.88)$ was obtained supporting the percentages obtained. On whether there are quality procedures followed as a measure for loan disbursement in the Bank, 50.8\% of the respondents agreed while $19 \%$ strongly agreed bringing the total to $69.8 \% .28 .6 \%$ of the respondents were neutral while only $1.6 \%$ disagreed. A mean score of $3.87(\mathrm{SD}=0.73)$ was obtained. The last statement was on whether the employees are aware of the 
effect of each risk exposure to the Bank and therefore are careful to report any suspicious dealings. To this $69.8 \%$ of the respondents strongly agreed and $25.4 \%$ agreed. In total, it showed that $95.2 \%$ of the respondents were in agreement. The mean score of 4.65 attested to this while the standard deviation $(\mathrm{SD}=0.57)$ showed minimal divergence of the responses. The overall mean obtained in relation to risk measurement as an indicator of risk management was $4.40(\mathrm{SD}=0.72)$.

Table 4.5: Model summary and ANOVA on risk assessment

\begin{tabular}{ll}
\hline Particular & Profitability \\
\hline Constant & $1.665^{* *}(0.000)$ \\
Risk Identification & $0.237^{* *}(0.000)$ \\
Risk Classification & $-0.051(0.437)$ \\
Risk Measurement & $0.373^{* *}(0.000)$ \\
$\mathrm{R}$ & 0.647 \\
$\mathrm{R}^{2}$ & 0.418 \\
$\mathrm{Adj} \mathrm{R}^{2}$ & 0.388 \\
F-statistics(p-value $)$ & $14.127^{* *}(0.000)$ \\
\hline p-values are in brackets, ${ }^{*}$ Significant at $0.01,{ }^{* *}$ Significant at 0.05
\end{tabular}

p-values are in brackets, ${ }^{*}$ Significant at $0.01,{ }^{* *}$ Significant at 0.05

Source: Primary data (2021)

Table 4.5 shows the regression output table based on the model summary and the analysis of variance. As shown in the table, risk assessment has an influence on the profitability of Urwego Bank since the model was found to be significant at $5 \%(\mathrm{~F}=14.127, \mathrm{p}<0.05)$. In addition, risk measurement, risk identification and risk classification, which were used as indicators of risk assessment, gave an output of $\mathrm{R}=0.647$ and $\mathrm{R}^{2}=0.418$. This revealed that the combined effect of risk measurement, risk identification and risk classification influence $41.8 \%$ of the profitability of the bank. Table 4.5 further provides analysis for each of the indictor variables. As shown in the table, risk identification has a positive and significant coefficient $\left(\mathrm{p}_{1}=0.237, \mathrm{p}<0.05\right)$, risk

classification has a negative and insiginifanct effect $\left(\mathrm{p}_{2}=-0.051, \mathrm{p}=0.437\right)$ while risk measurement has a positive and significant $(\mathrm{p} 3=0.373, \mathrm{p}<0.05)$ effect on profitability of the Bank.

\subsection{Findings on the relationship between risk control and profitability of Urwego Bank, Rwanda} Table 4.6 Respondent's view on internal control systems

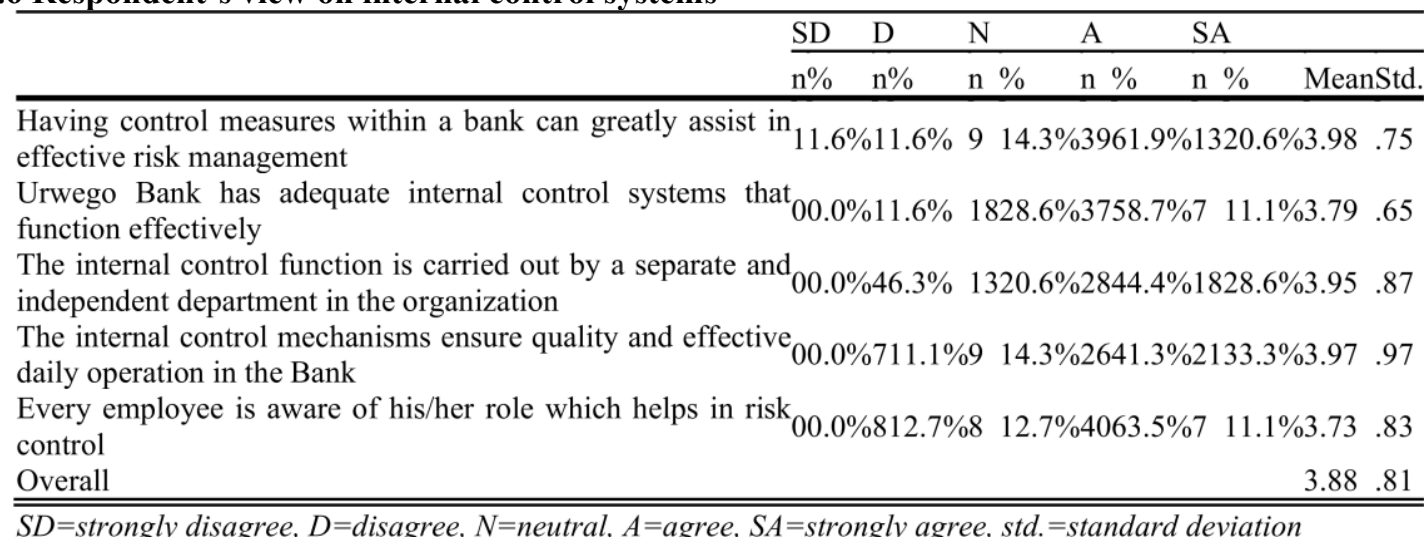

Source: Primary data (2021)

The second objective was formulated around risk control measures that the Bank undertakes to ensure sound risk management practices and how this affects the Bank's profitability. To achieve this objective, the key indicators used were internal control systems, risk mitigation measure and risk financing. All these were measured on a fivepoint Likert scale from strongly disagree to strongly agree with score of 1-5. On whether having control measures within a bank can greatly assist in effective risk management, $61.9 \%$ of the respondents agreed and another $20.6 \%$ strongly agreed giving a total of $82.5 \%$ of those in agreement. The rest of the respondents indicated neutral $(14.3 \%)$, disagree $(1.6 \%)$ and strongly disagree $(1.6 \%)$. This results then gave a mean score of $3.98(\mathrm{SD}=0.75)$ indicating the views were concentrated on the agreement. On whether Urwego Bank has adequate internal control systems that function effectively, $58.7 \%$ of the respondent agreed and $11.1 \%$ strongly agreed totaling to $69.8 \%$ of those in agreement. On the other hand, $28.6 \%$ and $1.6 \%$ of the respondents indicated neutral and disagree, respectively. The results for these showed a mean of 3.79 and a standard deviation of 0.65 .

Table 4.6 also shows the results of the respondents' views on the statement that the internal control function is carried out by a separate and independent department in the organization. To this, $44.4 \%$ and $28.6 \%$ of the respondents agreed and strongly agreed respectively totaling to $73 \%$. The remaining were distributed as $20.6 \%$ neutral and $6.3 \%$ disagree. The mean score obtained was $3.95(\mathrm{SD}=0.87)$ which revealed there were divergence in responses but with majority in agreement. In addition, the research sought to find out the respondent's views on 
whether the internal control mechanisms ensure quality and effective daily operation in the Bank. $41.3 \%$ agreed while $33.3 \%$ strongly agreed with the statement, giving a total of $74.4 \%$ of the respondents in agreement. This is supported by a mean score of $3.97(\mathrm{SD}=0.97)$ which implied that the responses were concentrated on the agreement. The last statement for this indicator sought to find out the contribution of the employees' awareness of their roles on risk control. $63.5 \%$ agreed plus $11.1 \%$ strongly agreed giving a total of $74.6 \%$ of the respondents who were in agreement that employees' awareness of their roles improves internal control. The overall mean for this indicator was $3.88(\mathrm{SD}=0.81)$ showing despite the divergence views, majority were crowded on the agreement that internal control systems contribute to the overall risk management practices of the Bank. Rwayitare et al. (2016) in their research indicated the need for risk monitoring as a precursor for financial performance in the banking industry.

Table 4.7: Respondent's view on risk mitigation

\begin{tabular}{|c|c|c|c|c|c|c|c|c|c|c|c|}
\hline & $\underline{\mathrm{SD}}$ & \multicolumn{2}{|l|}{$\mathrm{D}$} & \multicolumn{2}{|l|}{$\mathrm{N}$} & \multicolumn{2}{|l|}{ A } & \multicolumn{2}{|l|}{ SA } & \multirow[b]{2}{*}{ Mean } & \multirow[b]{2}{*}{ Std } \\
\hline & $\mathrm{N} \%$ & $\mathrm{n}$ & $\%$ & $\mathrm{n}$ & $\%$ & $\mathrm{n}$ & $\%$ & $\mathrm{n}$ & $\%$ & & \\
\hline $\begin{array}{l}\text { Risk mitigation strategies are effective } \\
\text { ways of reducing the possibility of } \\
\text { occurrence of risk and their impact in } \\
\text { an organization }\end{array}$ & $0 \quad 0.0 \%$ & 2 & $3.2 \%$ & 15 & $23.8 \%$ & 25 & $39.7 \%$ & 21 & $33.3 \%$ & 4.03 & .84 \\
\hline $\begin{array}{l}\text { The Bank has put in place risk } \\
\text { mitigation strategies to reduce the } 1 \\
\text { occurrence and the impact of risks }\end{array}$ & $1 \quad 1.6 \%$ & 24 & $38.1 \%$ & 20 & $31.7 \%$ & 14 & $22.2 \%$ & 4 & $6.3 \%$ & 2.94 & .97 \\
\hline $\begin{array}{l}\text { All the mitigation strategies are } \\
\text { formulated along the Bank strategic } 0 \\
\text { plans and management meetings }\end{array}$ & $0 \quad 0.0 \%$ & 1 & $1.6 \%$ & 9 & $14.3 \%$ & 32 & $50.8 \%$ & 21 & $33.3 \%$ & 4.16 & .72 \\
\hline $\begin{array}{l}\text { Each department within the Bank has } \\
\text { its own risk mitigation plans well } 1 \\
\text { communicated to all parties in the } \\
\text { department }\end{array}$ & $1 \quad 1.6 \%$ & 4 & $6.3 \%$ & 16 & $25.4 \%$ & 38 & $60.3 \%$ & 4 & $6.3 \%$ & 3.63 & .77 \\
\hline Overall & & & & & & & & & & 3.69 & .83 \\
\hline
\end{tabular}

Source: Primary data (2021)

The second indicator for risk control measures used in this research was risk mitigation. The results obtained through the use of questionnaire are displayed in Table 4.8. As shown in the table, 39.7\% and 33.3\% of the respondents agreed and strongly agreed respectively on the statement that risk mitigation strategies are effective ways of reducing the possibility of occurrence of risk and their impact in an organization. $23.8 \%$ were neutral while $3.2 \%$ disagreed giving a mean score of 4.03 and standard deviation of 0.84 . On whether the Bank has put in place risk mitigation strategies to reduce the occurrence and the impact of risks, $1.6 \%$ strongly disagreed, $38.4 \%$ of the respondents disagreed and $31.8 \%$ were neutral. Only $22.2 \%$ agreed and $6.3 \%$ of the respondents strongly agreed. This therefore gave a mean score of $2.94(\mathrm{SD}=0.97)$ showing that majority of the views were crowded on the disagreement side.

On whether all the mitigation strategies are formulated along the Bank strategic plans and management meetings, Table 4.7 shows that $50.8 \%$ of the respondents agree and $33.3 \%$ strongly agreed. This totaled to $84.1 \%$ of those respondents who were in agreement. On the other side, $14.3 \%$ of the respondents were neutral while only $1.6 \%$ disagreed with the statement. The mean score of 4.16 showed the responses were concentrated on agreement while a standard deviation of 0.72 showed relative divergence. The last statement was concerned on whether each department within the Bank its own risk mitigation has plans well communicated to all parties in the department. To this, $60.3 \%$ of the respondents agreed and $6.3 \%$ strongly agreed, giving a total of $66.6 \%$ of the respondents who were in agreement. The mean score of $3.63(\mathrm{SD}=0.77)$ was obtained while the overall mean score for risk mitigation was $3.69(\mathrm{SD}=0.83)$, indicating that most of the responses on the statements were crowded on the neutral. Similar research by Goldberg \& Palladini, (2010) shows the need to adopt and innovate risk management tools used by the larger banks that may help in creating optimal risk management culture within the organizations.

Table 4.8: Respondent's view on risk financing

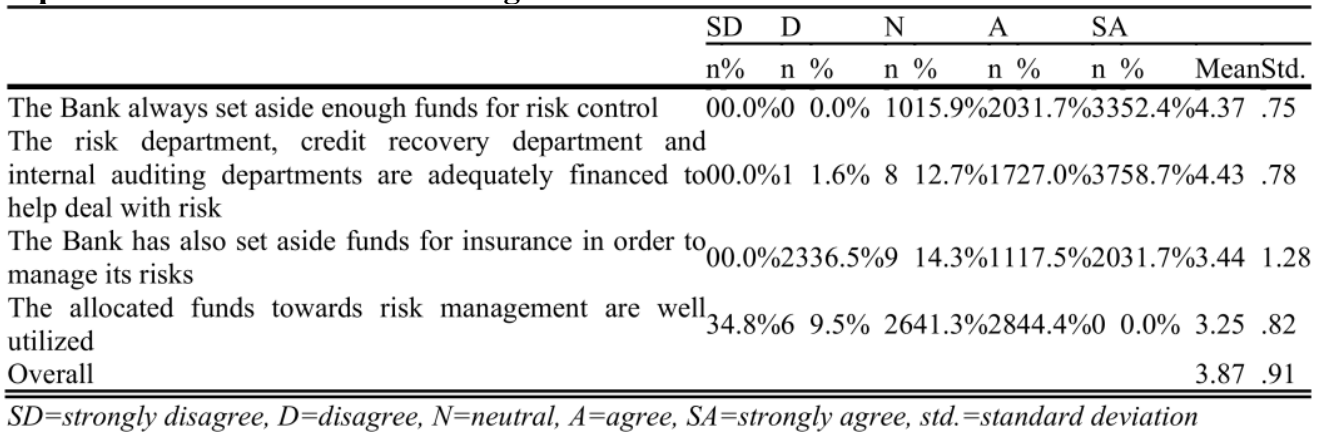

Source: Primary data (2021) 
The Table 4.8, the responses about the Bank always set aside enough funds for risk control showed that $52.4 \%$ of the respondents strongly agreed and $31.7 \%$ agreed with the statement. It also shows that $15.9 \%$ of the respondents were neutral. The resulting mean score was 4.37 with a standard deviation of 0.75 showing some divergence in views. On whether the risk department, credit recovery department and internal auditing departments are adequately financed to help deal with risk, $58.7 \%$ of the respondents strongly agreed and $27 \%$ agreed. This gives a total of $85.7 \%$ of the respondents in favor of this statement. The mean obtained was $4.43(\mathrm{SD}=0.78)$. On whether the Bank has also set aside funds for insurance in order to manage its risks, $31.7 \%$ of the respondents strongly agreed while $17.5 \%$ agreed with the statement. $14.3 \%$ were neutral while 36.55 disagreed. The results therefore gave a mean of $3.44(\mathrm{SD}=1.28)$ showing that most of the responses were concentrated on the neutral. Lastly, on whether the allocated funds towards risk management are well utilized, $44.4 \%$ agreed, $41.3 \%$ were neutral, $9.5 \%$ disagreed while $4.8 \%$ strongly disagreed. The mean score obtained

3.25 and a standard deviation of 0.82 . On the overall, risk financing as a method for under risk control measure obtained a score of 3.87 and a standard deviation of 0.91 .

Table 4.9: Model summary and ANOVA for risk control measures

\begin{tabular}{ll}
\hline Particular & Profitability \\
\hline Constant & $2.070^{* *}(0.000)$ \\
Risk Financing & $0.478^{* *}(0.000)$ \\
Internal Control Systems & $-0.74(0.353)$ \\
Risk Mitigation & $0.005(0.956)$ \\
$\mathrm{R}$ & 0.763 \\
$\mathrm{R} 2$ & 0.582 \\
AdjR2 & 0.561 \\
F-Statistics (p-value) & $27.388^{* *}(0.000)$ \\
\hline p-values are in brackets, ${ }^{*}$ Significant at $0.01,{ }^{* * *}$ Significant at 0.05
\end{tabular}

Source: Primary data (2021)

On using the regression analysis to investigate the relationship between risk control measures and profitability of Urwego Bank, the results were displayed in Table 4.12. According to the findings, the regression model was found to be significant at $5 \%(\mathrm{~F}=27.388, \mathrm{p}<0.05)$. Moreover, the model fits in explaining the relationship as shown by $\mathrm{R}=0.763$ and $\mathrm{R}^{2}=0.582$. This showed that $58.2 \%$ of the changes of profitability of the Bank are influenced by risk control measures. However, despite the results of significance regression model and a combined effect of the three indicator variables on profitability, an investigation on the individual variable contribution showed that only risk financing is positive and significantly effective $\left(\mathrm{p}_{3}=4.843\right.$, $\left.\mathrm{p}<0.05\right)$. The regression coefficient on internal control systems is negative and insignificant $\left(\mathrm{p}_{1}=-0.074, \mathrm{p}=0.353\right)$ while that of risk mitigation was positive but also insignificant $\left(\mathrm{p}_{2}=0.005, \mathrm{p}<0.956\right)$. This was interpreted to mean that when considered individually the control measure may not have significant effect on profitability (except for risk financing). It was therefore concluded that the risk control measures, that is, internal control systems, risk mitigation and risk financing ought to be practiced concomitantly in order to have significant effect on profitability of the microfinance banks.

\subsection{Findings on the effect of risk monitoring on the profitability of Urwego Bank, Rwanda}

Table 4.10: Respondents' views on risk evaluation

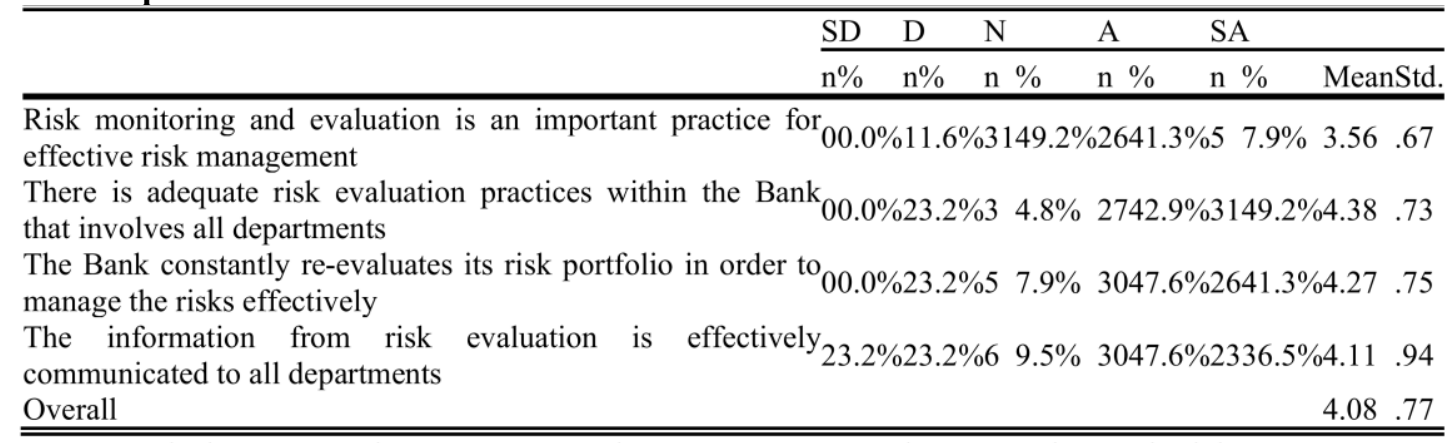

SD=strongly disagree, $D=$ disagree, $N=$ neutral, $A=$ agree, $S A=$ strongly agree, std $=$ standard deviation

Source: Primary data (2021)

Table 4.10 shows the results from five-point Likert scale ranging from strongly disagree (1) to strongly agree (5) obtained in regard to risk evaluation as a key indicator of risk monitoring. On whether risk monitoring and evaluation is an important practice for effective risk management, $41.3 \%$ agreed and $7.9 \%$ strongly agreed bringing the total of those in agreement to $59.2 \% .49 .2 \%$ of the respondents were neutral while $1.6 \%$ disagreed with the statement. The mean score obtain in this regard was 3.56 with standard deviation of 0.67. Concerning the statement if there are adequate risk evaluation practices within the Bank that involves all departments, $49.2 \%$ and $42.9 \%$ of the respondents strongly agreed and agreed respectively with the statement. This showed that a total of $92.1 \%$ agreed about the risk evaluation practices. This was also supported with the mean score of $4.38(\mathrm{SD}=0.73)$. 
were neutral and $1.6 \%$ disagreed.

The average score that was obtained (mean=4.06, $\mathrm{SD}=0.72$ ) showed that the responses were more concentrated on agreement. Lastly, the statement on whether inputs from various parties or departments in relation to risk are respected by the Bank management, 3.2\% disagreed, $4.8 \%$ were neutral, $42.9 \%$ agreed and $49.2 \%$ strongly agreed. The average score in this case (mean $=4.38, \mathrm{SD}=0.73$ ) showed that the respondents agreed while the standard deviation indicated a relative divergence. The overall mean score regarding system upgrade as an indicator of monitoring (mean=4.00, $\mathrm{SD}=0.87$ ) showed that this variable was selected as a key indicator of risk monitoring in Urwego Bank.

Table 4.13: Regression model and ANOVA for risk monitoring

\begin{tabular}{ll}
\hline Particulars & Profitability \\
\hline Constant & $1.460^{* *}(0.022)$ \\
Risk Evaluation & $0.438^{* *}(0.000)$ \\
System Update & $0.037^{*}(0.070)$ \\
Feedback System & $0.063^{*}(0.052)$ \\
R & 0.503 \\
R2 & 0.253 \\
AdjR2 & 0.215 \\
F-Statistics (p-value) & $6.652^{* *}(0.001)$ \\
\hline p-values are in brackets, ${ }^{*}$ Significant at $0.01,{ }^{* * *}$ Significant at 0.05
\end{tabular}

Source: Primary data (2021)

As shown in Table 4.13, the regression model regarding the risk monitoring was found to be significant $(\mathrm{F}=$ $6.652, \mathrm{p}<0.05)$ at $5 \%$ level of significance since the calculate $\mathrm{p}$-value was less than 0.05 . The reported $\mathrm{R}$ and $\mathrm{R}^{2}$ showed that the model was significantly fit $\left(R=0.503, R^{2}=0.253\right)$ for analysis. The $R^{2}$ revealed that $25.3 \%$ of the profitability in Urwego Bank is influenced by risk monitoring processes. According to the regression output given in Table 4.13, all the indicator variables were found to be significantly and positively related to the profitability of the bank. Risk evaluation ( $\left.\mathrm{p}_{1}=0.438, \mathrm{p}<0.05\right)$ was positively and significant effect on profitability, feedback system $\left(\mathrm{p}_{2}=0.063, \mathrm{p}=0.052\right)$ was found to be positive and has a significant effect on profitability. Similarly, the system upgrade $\left(\mathrm{p}_{3}=0.037, \mathrm{p}=0.07\right)$ as a risk monitoring tool was also found to be positive but only significant at $10 \%$ level of significance.

Table 4.14: Regression models and ANOVA on the dependent variables

\begin{tabular}{lllll}
\hline Particulars & Interest Margin & ROA & ROE & Profitability \\
\hline Constant & $4.541^{* *}(0.000)$ & $-1.187(0.176)$ & $-0.757(0.327)$ & $0.865(0.130)$ \\
Risk Assessment & $-0.580^{* *}(0.001)$ & $0.493^{* *}(0.003)$ & $0.249(0.080)$ & $0.054^{* *}(0.016)$ \\
Risk Control & $-0.024(0.792)$ & $0.574^{* *}(0.000)$ & $0.632^{* *}(0.000)$ & $0.394^{* *}(0.000)$ \\
Risk Monitoring & $0.474(0.15)$ & $0.083(0.646)$ & $0.225(0.162)$ & $0.261^{* * *}(0.030)$ \\
$\mathrm{R}$ & 0.460 & 0.739 & 0.784 & 0.732 \\
$\mathrm{R}^{2}$ & 0.212 & 0.546 & 0.614 & 0.536 \\
AdjR $^{2}$ & 0.172 & 0.523 & 0.594 & 0.512 \\
F-Statistics (p-value) & $5.287^{* *}(0.003)$ & $23.663^{* *}(0.000)$ & $31.287^{* *}(0.000)$ & $22.695^{* *}(0.000)$ \\
\hline p-values are in brackets, ${ }^{*}$ Significant at 0.01, ${ }^{* *}$ Significant at 0.05 & &
\end{tabular}

Source: Primary data (2021)

Table 4.14 shows the regression and analysis of variance outputs for all the dependent variables, namely interest margin, return on asset (ROA), return on equity (ROE) and profitability. As shown in the results, the regression model was a significant one $(\mathrm{F}=5.287, \mathrm{p}<0.003)$ at $5 \%$ since the p-value calculated was less than 0.05 . In addition, the $\mathrm{R}^{2}$ of the model showed that $21.2 \%$ of the profitability in terms of interest margin can be attributed to the risk management practices adopted by Urwego Bank. Further analysis of the individual contribution of the risk management practices on interest margin was conducted and the results presented in Table 4.16. As revealed both risk assessment $\left(\mathrm{p}_{1}=-0.58, \mathrm{p}<0.05\right)$ and risk monitoring $\left(\mathrm{p}_{3}=0.474, \mathrm{p}<0.05\right) \quad$ were

significant at $5 \%$ though the coefficient for risk assessment negatively affects interest margin. The regression coefficient of risk monitoring $\left(\mathrm{p}_{2}=-0.24, \mathrm{p}=0.792\right)$ was negative and showed no significant influenc on interest margin. This clearly revealed that risk monitoring has no significant effect on interest margin, especially when considered individually.

The regression analysis as displayed in Table 4.16 also shows that the output was significant at $5 \%(\mathrm{~F}=23.663, \mathrm{p}$ $<0.05)$. In addition, the $\mathrm{R}$ and the $\mathrm{R}^{2}$ gave significant goodness-of-fit $\operatorname{model}\left(\mathrm{R}=0.739, \mathrm{R}^{2}=0.546\right)$. This showed that the model explains $54.6 \%$ of the changes in profitability of Urwego Bank as measured by return on assets. The analysis of the regression coefficients of the three independent variables was done and represented in Table 4.16. As shown in the table, both risk assessment $\left(\mathrm{p}_{1}=0.493, \mathrm{p}<0.05\right)$ and risk control systems $(\mathrm{p} 2=$ $0.574, \mathrm{p}<0.05)$ contribute positively and significantly to the profitability of Urwego Bank as measured using return on assets. On the other hand, risk monitoring as a risk management practice was found to be positive $(\mathrm{p} 3=$ $0.083, \mathrm{p}=0.646$ ) but not significant in regard to its individual contribution to profitability of Urwego Bank. 
Similarly, the regression analysis conducted on profitability as measured using return on equity revealed that the model was significant $(\mathrm{F}=31.287, \mathrm{p}<0.05)$ at $5 \%$ threshold. In addition, the $\mathrm{R}=0.784$ and $\mathrm{R}^{2}=0.614$ revealed the model to be fit showing that $61.4 \%$ of the profitability in terms of ROE can be attributed to risk management practices. Table 4.16 also related to the regression analysis of the dependent variables, risk assessment, risk control systems and risk monitoring on return on equity proxy for profitability. In the results, risk assessment (p1 $=0.249, \mathrm{p}<0.05)$ and risk control systems $\left(\mathrm{p}_{2}=0.632, \mathrm{p}<0.05\right)$ were found to have positive and significant effect on the profitability of Urwego Bank as measured by return on equity. On the risk monitoring $(\mathrm{p} 3=0.225, \mathrm{p}$ $=0.162$ ), there was no significant effect on profitability of the Bank as indicated by a p-value greater than $5 \%$.

Lastly, the researcher investigated the overall effect of risk management practices on the profitability of Urwego Bank. To achieve this, the indicators of profitability, namely, interest margin, return on asset and return on equity, were combined to one variable through linear transformation to created one variable profitability. Then, independent variables were regressed on this variable and the results are presented in Table 4.16. The table shows that the model was significant $(\mathrm{F}=22.695, \mathrm{p}<0.05)$ at $5 \%$ since the calculated $\mathrm{p}$-value was higher than $5 \%$. The results also revealed that $\mathrm{R}=0.732$ and $\mathrm{R}^{2}=0.536$ showing that $53.6 \%$ of the profitability of Urwego Bank can be attributed to the risk management practices that the Bank adopts. Similar to this conclusion is the findings pointed out by Ghani and Mahmoodb (2015) and Knewtson and Qi (2019). Table 4.14 is also related to the regression coefficient output obtained in the regression of the independent variables on the profitability of the Bank. As shown in the table, risk assessment $\left(\mathrm{p}_{1}=0.054, \mathrm{p}<0.05\right)$ was found to have a

positive and significant effect on profitability of the Bank, risk control system ( $22=0.394, \mathrm{p}<0.05)$ was also found to be positively and significantly related to profitability. Finally, risk monitoring ( $33=0.261, \mathrm{p}<0.05$ ) was also found to have positive and significant effect on profitability of the Bank. Hence the overall regression model was formulated as shown in this equation. profitabilty $=0.865+0.054 *$ risk assessment $+0.394 *$ risk control $+0.261 *$ risk monitoring $+\mathrm{c}$

Table 4. 15: Performance indicators of Urwego Bank

\begin{tabular}{llllll}
\hline Items & $\mathbf{2 0 1 6}$ & $\mathbf{2 0 1 7}$ & $\mathbf{2 0 1 8}$ & $\mathbf{2 0 1 9}$ & $\mathbf{2 0 2 0}$ \\
\hline Total assets & $22,413,687$ & $21,341,492$ & $20,596,704$ & $21,350,765$ & $23,397,478$ \\
Total equity & $3,134,784$ & $3,229,178$ & $2,742,676$ & $3,220,741$ & $3,430,178$ \\
Net Interest income & $2,762,316$ & $2,753,670$ & $1,299,387$ & $2,950,503$ & $2,754,767$ \\
Operating profit & $-1,831,006$ & $-1,432,332$ & $-404,076$ & $-352,426$ & $-1,210,635$ \\
ROA & -8.17 & -6.71 & -1.96 & -1.65 & -5.17 \\
ROE & -58.41 & -44.36 & -14.73 & -10.94 & -35.29 \\
NIM & -66.29 & -52.02 & -31.10 & -11.94 & -43.95 \\
\hline
\end{tabular}

Source: Secondary data (Annual reports of Urwego Bank for the years 2016-2020)

The results in Table 4.15 on secondary data obtained from the financial statement of Urwego Bank were accessed on the period of time covered in this research. Table 4.2 shows the results for total assets, total equity, interest income and operating profit (all in 000Rwf). It also shows the ratios ROA and ROE for years 2016- 2020. The main purpose of the data was to provide a picture of the trend of the financial performance of the Bank over the coverage period. As shown, the trend indicates that the Bank has been on a decline and there is need to improve the profitability of the Bank.

\subsection{Discussion}

The results presented in the previous section have looked at the effect of risk management practices and their effect on the profitability on Urwego Bank. The main indicator variables for the independent variable were risk assessment, risk control systems and risk monitoring. The indicators of profitability as the dependent variable on the other hand, included interest margin, return on assets, and return on equity. The regression analysis has revealed that there is a combined effect of risk measurement, risk identification and risk classification as measures of risk assessment on the profitability of the bank. This clearly indicates that risk assessment is an important factor that bank managers and especially the risk managers ought to pay attention to. Moreover, there was considerable positive effect of risk identification and risk measurement on the profitability of the Bank. These results were congruent to the findings by other authors Raghavan (2017) and (Chapelle, 2019) who suggested the need for risk assessment procedure for efficient operation of the banking industry.

In addition, the findings on the risk control measures on the profitability of Urwego Bank showed that there was significant relationship between the variables. The indicators variables for risk control measures in this regard were internal control systems, risk mitigation and risk financing. These were found to have a significant combined effect but only risk financing showed individually a positive and significantly effective. It was therefore concluded that the risk control measures, that is, internal control systems, risk mitigation and risk financing ought to be practiced concomitantly in order to have significant effect on profitability of the microfinance banks. The results showed that risk control measures are important for the profitability of the microfinance banks, but they should be practiced in totality to improve their effect on profitability. Similar to this conclusion is the findings 
pointed out by Ghani and Mahmoodb (2015) and Knewtson and Qi (2019).

The regression model regarding the risk monitoring was found to be significant to the profitability of Urwego Bank. All the indicator variables of risk monitoring including risk evaluation, feedback system and system upgrade were found to be significantly and positively related to the profitability of the Bank. This clearly showed the importance of risk monitoring to improve the risk management practices as well as influence the profitability of MFBs. As noted also by Bessis (2011) system upgrades are done to accommodate the changes to increase or reduce the risk portfolio depending on the outcome of the risk monitoring.

\subsection{Conclusion}

The current research was centered on the risk management practices as contributing factors to the profitability of microfinance banks in Rwanda. For better analysis, three indicators of the risk management practice, namely, risk assessment, risk control measures and risk monitoring were used. On the other hand, profitability in the microfinance bank was measured using interest margin, return on assets and return on equity. As discussed in the finding's sections, it was clearly found out that these risk management practices are important factors in creating an effective risk management environment.

Since the banking industry, more so, the microfinance banks are prone to experience risk in their daily operation, having risk management practices can help the banks to proactively deal with the risk. In this regard, it would be important for the banks to have in place effective risk management practices that should be well formulated and communicated to all employees. More importantly, have cut out roles and duties of the various staff and departments are an important aspect in the risk management. As shown in the regression analysis, all the identified risk management practices have a contributing effect on the profitability. However, when considered individually, some like risk monitoring may have insignificant and negative effect on the profitability. This was a clear indication that led to the conclusion that the risk management practices should be carried out in a holistic manner and within one framework. Trying to isolate the practices from each other would be detrimental and incur additional costs that may hinder the monitoring and the efficiency of the entire system. In fact, it is important that the banking industry concentrates on the overall effort of risk management combining all the aspects therein including risk assessment, risk control measures and risk monitoring. It is with this framework that an effective and efficient model can be achieved. In turn this can reduce volatility of the banks in terms of profit fluctuations and risk exposure rate.

\subsection{Acknowledgement}

The process of writing this research has seen the collaborative efforts and inputs of various people whom I now take time to say thank you. I direct my gratitude to my fellow classmates for the journey that we have travelled together in my entire studies and especially during the research writing process? I also thank my lecturers at Mount Kenya University, Rwanda. I also take this opportunity to extend my heart felt gratitude for Urwego Bank for having afforded me such an opportunity to base my study. I also thank all the respondents who took their time to respondent to the questionnaires distributed. My gratitude also goes to my family members who have stood with me and offered moral support towards my journey. To all those who have contributed to my progress so far, Thank you. God be with you all.

\section{References}

[1].Bessis, J. (2011). Risk management in banking. USA: John Wiley \& Sons.

[2].Byamungu, E., Nkechi, I. E., \& Ogoi, H. J. (2019). Effect of Risk Management Practices on Corporate Investment of Financial Institutions in Rwanda: A Case Study of Selected Commercial Banks. European Journal of Business and Management Research, 4(4):13-25.

[3].Chapelle, A. (2019). Operational Risk Management: Best Practices in the Financial Services Industry. UK: John Wiley \& Sons.

[4].Ghani, R. A., \& Mahmoodb, R. (2015). Risk management practices and performance of microfinancing banks in Malaysia. Academia Journal UiTMT, 4(2): 26-33.

[5].Goldberg, M., \& Palladini, E. (2010). Managing risk and creating value with microfinance. Washington DC: The World Bank.

[6].Irawati, N., \& Maksum, A. (2018, January). The Impact of Risk Management and Bank Size on Profitability Of Commercial Banking In Indonesia. In 1st Economics and Business International Conference 2017 (EBIC 2017). Paris: Atlantis Press.

[7].Kamau, P. M. (2010). Adoption of risk management by commercial banks in Kenya (Doctoral dissertation, University of Nairobi).

[8].Knewtson, H., \& Qi, H. (2019). Managing risk for sustainable microfinance. The Journal of Risk Finance. 20(1): 2-13.

[9]. Lee, J.J. (2014). Improving Regulatory Framework for MFBs and NB MFIs in Rwanda. Rwanda: Access to Finance Rwanda.

[10]. Mohamed, A. M., \& Onyiego, G.(2018). Effect of risk management on financial performance of commercial banks in Kenya: a case study of commercial banks in Mombasa County. Strategic Journal of business and change 5(4): 1605-1630.

[11]. Olalekan, L. I., Olumide, M. L., \& Irom, I. M. (2018). Financial risk management and the profitability: an 
empirical evidence from commercial banks in Nigeria. Samuel Analyst Journal of Management Sciences, 16(2): 56-67.

[12]. Raghavan, R. (2017). Risk, the Business Driver in Banks. Indian Journal of Agricultural Economics, 72(1), 129-131.

[13]. Rwayitare, J.B., Shukla, J. and Ruhara C. (2016). Credit Risk and Commercial Bank Profitability in Rwanda.

[14]. International Journal of advanced Research, 4(9): 294-325.

[15]. Sabeza, F., Shukla, J., \& Bajpai, G. (2015). Assessing Credit Risk Management Practices and Performance of Commercial Banks in Rwanda. International Journal of Social Science and Humanities Research. Kigali, 10(3): 323-333.

[16]. Sun, C., \& Chang, X. (2018). The Impact of Credit Risk on Profitability of Commercial Banks. International Journal of business 25: 12-23.

[17]. Ugirase, J. M. (2013). The effect of credit risk management on the financial performance of commercial banks in Rwanda (Unpublished MBA dissertation).

[18]. Zou, Y., \& Li, F. (2014). The impact of credit risk management on profitability of commercial banks: A study of Europe. Journal of business economics 12(4): 123-134. 